\title{
THE LEADERSHIP MODEL AND THE USE OF PUBLIC PARTICIPATION INSTRUMENTS. THE CASE OF POLISH MUNICIPALITIES
}

\begin{abstract}
The aim of the article is to describe and evaluate the relationship between the leadership model implemented by the executive bodies of Polish municipalities and the use of public participation instruments. The author focuses on the executive bodies of the municipalities due to their significant position in the structure of local government. The main hypothesis adopted in the paper assumes that the use of public participation instruments depends on the style of local leadership. The mayors who are both formal leaders and social leaders tend to incorporate participatory mechanisms in local governance processes more often than those who are only formal leaders. The theoretical framework of the article is determined by the theories of transformational and participative leadership. The article was based on survey research and in-depth interviews. The research results show no clear differences between the scope of applied instruments of participation and the type of leadership. The scale of social support has little impact on the scope of applied mechanisms of participation.
\end{abstract}

Keywords: local leadership, transformational leadership, participative leadership, public participation, social leader.

\section{INTRODUCTION}

The scale of using public participation instruments in municipalities depends on a number of internal as well as external factors. The internal factors include the modes of governance (leadership model) implemented by mayors. A leadership model determines the relations with members of local communities, shapes the administrative and political culture of the unit, influences the specificity of communication in the municipality, and affects the directions of the municipality development and implementation of public policies as well as the mode of governing the territorial unit. Treating instruments of participation as tools enabling the influence of local communities on the shape of changes in the public sphere, it can be assumed that the leadership model determines their selection, the scope of their application and the areas (policies) in which they apply.

The purpose of this article is to verify whether the method of exercising power in municipalities (especially by the executive body) influences the use of tools for participation. Basing on the results of quantitative and qualitative research carried out in $2017-2018^{2}$, the

1 Anna Kołomycew, PhD, Institute of Political Science, University of Rzeszów, correspondence address: Institute of Political Science University of Rzeszow, al. mjr. W. Kopisto 2a, 35-959 Rzeszów, e-mail: anna.kolomycew@ur.edu.pl. ORCID: 0000-0003-2105-2953.

2 The research carried out within the project "Cooperation instruments in the public policies implementation process" no. INoP-05/2017/508 financed by the MNiSW as a grant for the Faculty of 
author undertook to verify the following hypothesis: the use of public participation instruments depends on the style of local leadership. The mayors who are both formal leaders and social leaders tend to use instruments of participation in governance processes more often than those who are only formal leaders.

Aiming to verify the above hypothesis, the author tried to answer the following questions: what model of leadership was used in the analyzed municipalities? does the size of a municipality matter when it comes to using public participation instruments? do the people exercising the function of mayors who enjoy social support (greater than necessary to gain a function - victory in the election) use public participation tools more frequently and consider the opinions of the local community when making decisions?

At the theoretical level, the article was embedded in leadership theories, with particular emphasis on transformational and participatory leadership. The research was conducted using quantitative methods (telephone survey) and qualitative (individual in-depth, semistructured interview with the use of a scenario). Furthermore, the analysis of the literature on the subject, the comparative method and elements of the decision-making method were used.

\section{SEARCHING FOR PERFECT LEADERSHIP MODEL}

\subsection{Transformational leadership. The first step towards a participatory model?}

Leadership is not a new subject of research. On the contrary, the theories developed over decades allow for distinguishing various trends in leadership theories that emphasize different aspects of the process and the roles of the actors involved (Avolio, Walumbwa, Weber, 2009; Gill, 2011, cf. Lang 2014). With regard to the subject of research, the concepts that do not focus on the leader alone, but also consider other actors of the leadership process are of significant importance (Rabie, 2013). One of the most popular theoretical approaches of the so-called new genre is the model of transformational leadership. Its universal though not without its flaws- character contributed to its popularization in various disciplines, including political science (Bass, Riggio, 2006). However, it should be pointed out that this model is only sporadically analyzed in relation to the public sector (Moynihan, Pandey, Wright, 2014).

The model of transformational leadership was formulated in opposition to the transactional model, based on the exchange between the leader and his supporters (Burns, 1978; cf. Bass, 1985; Winkler, 2010). In the transformational model, the supporters were acknowledged as legitimate participants in the leadership process, without whom we could not de facto speak of leadership. The motives of the leader's involvement were also important. It could not be merely a desire to gain specific benefits, which was typical of the transactional model (Burns, 1978; Bass, 1985; Martin et. al., 2006). The transformational leader played the role of an educator, inspirer and motivator for activities. In a sense, the transformational leadership was similar to the charismatic leadership, because charisma is necessary to mobilize and motivate other people to act, but it is not the only determinant of this leadership model (Weber, 2009). It co-exists with an individual approach to other people and their intellectual stimulation (Bass, Wildman, Avolio, 1987; Bass, Riggio, 2006; Dawkins, 2011). Leaders

Sociology and History of the University of Rzeszów for conducting scientific research or development works and related tasks for the development of young scientists and participants of doctoral studies. 
of this kind must have additional qualities and skills that not only allow them to achieve their own goals, but also to develop relationships with other people and gain supporters (Bass, Avolio, 1994).

What seems to be an important aspect of the transformational leadership model - in the context of the analyzed research problem - is the delegation of competences. The transformational leader distributes tasks among other actors and thus shares his power to some extent (Arnstein, 1969; Quick, Bryson, 2016). The delegation of power that favors the development of both the leader himself and the activation of other people is, in the context of the public sector, an idealistic assumption, which undermines the application value of this approach. There is also the issue of differing values and declared but latent goals of leaders (Currie, Lockett, 2007; cf. Kołomycew, Kotarba, 2018a). However, some researchers indicate that this leadership model can be equally effective in the public and private sectors (Yang, Pandey, 2011; cf. Dumdum, Lowe, Avolio, 2002).

Despite delegating tasks to other people, the transformational leader does not lose his authority. He still holds a dominant position in the hierarchy. According to Bass and Riggio (2006), the way of gaining leadership does not really affect the style of exercising power. Both elected, appointed and even self-proclaimed leaders may turn out to be transformational leaders. The aforementioned authors point out that it is not possible to state unequivocally whether an elected leader is more likely to become a transformational leader. According to the authors, it should be assumed that elected leaders will enjoy a stronger support compared to the appointed and self-proclaimed ones. They will also have greater charisma and enjoy esteem and respect (Barbuto, Fritz, Matkin, 2001; Bass, Riggio, 2006). However, the fact that the leader has emerged from elections is not the only determinant of his strong position. What seems to be equally important is the efficiency of action, or at least the ability to convince others that it is so. To achieve that the leader needs a charisma, along with legitimacy and social recognition (Weber, 2009). In the long run, the leaders cannot rely on formal authority only. Though, as Bass and Riggio point out, transformational leaders supporting their decisions and actions with formal authority can be effective and gain new followers (Bass, Riggio, 2006).

\subsection{Participatory leadership - a perfect model?}

Another genre in leadership research is participative (democratic) leadership. This model assumes that individuals or their groups are included in the decision process at each of its stages, so they are informed about the plans and intentions of the decision-making body, they participate in the discussion on possible solutions to a given problem, and get involved at the stage of deciding and evaluating the adopted solutions (Saucier Lundy, Janes, 2009). While this leadership model - despite the existing limitations and drawbacks - may work for enterprises, it is much harder to apply in the public sector (Goleman, 2000; House et.al, 2014). As indicated by Saucier Lundy and Janes, in case of the public sector, participatory leadership is limited to the stage of dissemination of information regarding the object of decision making. It may, however, bring benefits such as strengthening the cohesion of the group and the empowerment of individuals or entire social groups. By including community members in decision-making processes, it is also possible to build a base of supporters. The disadvantage of using this approach, however, is an extended decisionmaking process and the risk of abandoning certain decisions altogether (Saucier Lundy, Janes, 2009). Another challenge is the activity of individuals. In the transformational model, 
the role of the leader was to activate and mobilize other people. The participative model takes for granted the activity of the remaining actors of the leadership process. However, the activity of local communities, or rather its lack, remains a significant problem of governance models based on the wide inclusion and involvement of people. The question arises then whether they are actually needed (Parvin, 2018).

In the participative leadership model, the task of the leader is to create a space for the activity of other entities. This means de facto abandoning some of his powers to other stakeholders. While he does not lose control over a given scope of tasks, he becomes merely one of many decision-makers. Participation creates opportunities for individuals and social groups to take part in the decision-making process (Bovaird, 2005; Bass, Bass, 2008;). It requires an effective way of communicating the people involved, efficient information flow and involvement in the matters that are actually important for the participants of the process and about which they have the appropriate scope of knowledge (Gress, 1974).

The leader, as already mentioned, is treated as one of many actors. He does not act as a facilitator, tutor, adviser, motivator or mentor, but a partner. In this model, participants cannot count on support, advice or the acquisition of new competences. And this may discourage them from further engagement $(\mathrm{Hu}, 2017)$. Another problem is a lack of stability resulting from the changes of stakeholders involved in resolving matters (WHO, 2016).

As a matter of fact, an active role of the leader is crucial for spreading participation (Bryson et.al, 2012). The mere approach to the issue of participation is differently understood in various communities and political systems. Social, cultural, political and economic factors determine both the scale of activity and community involvement in public affairs as well as the scope of opening public sphere to external entities. The leader should, above all, be able to identify the actors whose involvement will be important for solving specific problems and choose the right tools (Enserink, Monnikhof, 2003; cf. Friend, Hickling, 2005; Bryson et.al, 2012). According to Bryson, Crosby and Middleton Stone, leadership in a governance model based on participation can be realized in three forms (roles), i.e. a sponsor/protector, champion or facilitator (Crosby, Bryson, 2015).

The leader-protector is a person who enjoys formal authority and has the legitimacy to implement participatory solutions, inter alia, by adopting the rules of operation with the participation of stakeholders, indicating the tools, distributing resources for participation, pointing to the forms and directions of disseminating participatory solutions and ensuring the impact of decisions taken in cooperation with stakeholders on public policies (Bryson et.al, 2012). This model assumes that the formal leader ensures implementation of participative solutions and is their advocate. This is not quite the case with the leader-winner. First of all, he does not always have formal authority. Therefore, his activities are not strategic, but day-to-day, which results from the lack of possibility to administer the resources and make long-term decisions. This model is based on informal authority, charisma, and trust built on the effects of activity to date. The last type of the identified participatory leadership is a facilitator, i.e. the leader focused on helping other stakeholders in achieving their goals. This type of participatory leader is similar to the transformational leader due to the focus not so much on the results of the leadership process itself as on its course and the capacity to ensure such conditions that the remaining actors can achieve their own goals. The objective of such leaders is to encourage others to express their views. Leaders of this type are responsible for solving problems and ensuring the quality of a decision-making process. At the same time, they do not need to have formal authority to exercise this role. However, charisma and social trust are essential (Schwarz, 2005). 


\section{MAYOR - A FORMAL LEADER OR A SOCIAL LEADER?}

\subsection{Terminological explanations, methodology and research specifics}

The analysis of the issue of leadership at the local level focuses primarily on the executive body, especially a direct-elected one. As mentioned in the previous part of the article, formal leadership does not have to mean a strong social support for the executive body. Especially in the face of relatively low turnout in local government elections, which has been observed in Poland for years (Panicz, 2011; Żerkowska-Balas, A. Kozaczuk, 2013; PKW, 2018; cf. Król, 2018;). Although the position of the municipal executive body has been strengthened since the beginning of local government reforms, and especially after 2002 , this does not mean at the same time that the elected municipality head always enjoys high support (Mikołajczyk, 2011; Krukowska, 2018; Kołomycew, Kotarba, 2018b). In the article, the author distinguishes between formal leaders, i.e. elected for the position of mayor in direct elections, and social leaders who, apart from fulfilling a formal function, enjoy, as indicated by M. Weber, public recognition, characteristic for the charismatic leaders (Weber, 2009). Verification of the scale of social support which goes beyond the election results is difficult, because social support and acceptance of the current policy of the authorities are often expressed unofficially by the local community. This issue is rarely researched. The literature on local leadership focuses primarily on formal leadership and its models (Bennis, Nanus, 1985; Heifetz, Sinder, 1988; Chaleff, 1995; Kellerman, 1988). The situation when a formal leader is also a powerful social leader would be ideal from the point of view of the executive bodies of the municipalities ${ }^{3}$. The definitions of leadership closest to the understanding of the social leader were formulated by P. Żukiewicz, indicating that the leadership process itself is a social process in which individuals or groups express support for the person whom they recognize as a leader (Żukiewicz, 2011). In this perspective, a formal leader is at the same time a social leader. The support given to him stems from the fact that he is perceived by the supporters as the best fit for the position. At the same time, the process of becoming a leader requires time, gaining supporters, winning allies, building position and social trust (Sielski, 2012). No one becomes automatically a social leader at the moment of the election. The status must be worked out by an individual (Raczkowski, 2015; Habuda, 2007).

In an attempt to verify to what extent, the fact of combining the role of a formal leader and a social leader by municipal executive bodies influences the use of instruments of participation, the author conducted quantitative and qualitative research. The article, due to the limited volume of the text, presents only a part of the research results. Quantitative research (on the use of public participation tools at the local level), in the form of a telephone survey, was conducted in randomly selected municipalities (representative sample for Poland $\mathrm{N}=525$ ). The study was carried out in September 2017. In the next stage of the research, individual in-depth interviews were conducted in ten selected municipalities ${ }^{4}$.

\footnotetext{
${ }^{3}$ The literature on the subject often links a strong position of the executive body with the fact that it has been elected by direct suffrage. See more in: (Indulski, 2001; Nocoń, 2008; Sielski, 2012).

4 The method of selecting municipalities for qualitative research accounted for the type of municipality and the so-called participation rate formulated by the author of the research. On the basis of the responses included in the surveys, concerning the application of individual instruments of public participation in municipalities, the author has ranked municipalities into individual categories (district-based cities, urban, urban-rural and rural municipalities).
} 
For the purpose of the article, an indicator of social support for the executive body, enabling to verify whether a formal leader can be regarded at the same time as a social leader, was determined for ten municipalities in which in-depth interviews were conducted. Variables which allow to determine the stability of power and testify to the support provided to the executive body were considered. They included: number of terms (next term - strong position) (Krukowska, 2018; Gendzwiłł, P. Swianiewicz, 2017), the result of the elections in the 2014-2018 term (victory in the first round - strong position) (Gawlik, 2017), official social support during the election (type of committee, i.e. candidate's own committee, social committee or party support) (Źukiewicz, 2011), support of the municipality council in the 2014-2018 term (strong support of the municipality council - when more than half of the councilors came from the same electoral committee as the executive body) (Kuć-Czajkowska, Sidor, Wasil, 2017') and the result of voting on granting discharge during the previous term of office (the vote of approval) (Jakson, 2012). The table below presents the variables along with the assigned score and the total value of the "social support index - WSP".

Table 1. The indicator of social support (WSP) of the executive body in selected municipalities

\begin{tabular}{|l|c|c|c|c|c|c|}
\hline Municipality & $\begin{array}{c}\text { The num- } \\
\text { ber of } \\
\text { terms of } \\
\text { office of } \\
\text { a given } \\
\text { mayor }\end{array}$ & $\begin{array}{c}2014-2018 \\
\text { term of of- } \\
\text { fice- round } \\
\text { in the elec- } \\
\text { tions }^{2}\end{array}$ & $\begin{array}{c}\text { Support in } \\
\text { the elec- } \\
\text { tions }\end{array}$ & $\begin{array}{c}\text { The municipal } \\
\text { council sup- } \\
\text { port during } \\
\text { the 2014-2018 } \\
\text { term }\end{array}$ & $\begin{array}{c}\text { Granting } \\
\text { discharge in } \\
2014-2018 \\
\text { term }^{5}\end{array}$ & $\begin{array}{c}\text { WSP } \\
\text { value } \\
{[0-13]}\end{array}$ \\
\hline Brudzeń Duży & 1 & 2 & 3 & 3 & 2 & 11 \\
\hline Dobrzeń Wielki & 1 & 2 & 3 & 2 & 2 & 10 \\
\hline Gorlice & 0 & 1 & 1 & 0 & 1 & 3 \\
\hline Jedlicze & 0 & 1 & 3 & 3 & 2 & 9 \\
\hline Legnica & 3 & 1 & 4 & 1 & 0 & 9 \\
\hline Lubenia & 0 & 0 & 3 & 2 & 2 & 7 \\
\hline Opole Lubelskie & 2 & 0 & 3 & 2 & 2 & 9 \\
\hline $\begin{array}{l}\text { Piotrków Try- } \\
\text { bunalski }\end{array}$ & 2 & 2 & 4 & 2 & 2 & 12 \\
\hline Świdnik & 3 & 2 & 3 & 3 & 2 & 13 \\
\hline Warta & 2 & 0 & 3 & 3 & 2 & 10 \\
\hline
\end{tabular}

1 a) I - 0 points; b) II -1 point; c) III -2 points; d) IV -3 points

2 a) I round -2 ; b) II round with the advantage of at least $10 \%-1$ point; c) II round with the advantage of $1-10 \%-0$

${ }^{3}$ a) candidate's own committee -4, b) social committee -3 , c) independent candidate -2 ; c) a candidate with the support of a political party -1

${ }^{4}$ a) strong -3 points (strong support - over $50 \%$ members of the municipality council were from the same committee as the executive body); b) medium - 2 points (at least $1 / 3$ members of the council were from the same committee as the executive body) c) weak -1 point (below $1 / 3$ members of the council were from the same committee as the executive body); d) without support in the council - 0 (no councilors from the same committee as the executive body);

${ }^{5}$ a) always granted -2 ; b) it was not granted only once - 1 point; c) it was not granted more than once -0 points.

Source: author's own study. 
The indicator could reach a value between 0 and 13 points. For the purpose of the article, the author assumed that the value of the index in the range of 0-7 meant low public support for the executive body, and thus the person exercising this function (formal leader) was not a strong social leader at the same time, according to the understanding adopted in this article. Municipalities in the range 8-10 were considered "medium", while municipalities in the range of 11-3 "high", and their authorities (executive bodies) could be considered social leaders respectively.

In the municipalities selected for qualitative research, the author conducted individual in-depth interviews using the interview scenario. The group of respondents included representatives of the authorities (executive body, councilors), employees of individual municipal offices, and the people involved in the implementation of public participation tools ${ }^{5}$. In some municipalities, focus interviews were conducted. In total, 60 interviews were carried out.

\subsection{Leadership style and participation at the local level - research results}

The issue of creating conditions for social involvement and education of the community aimed at raising public awareness of the importance of undertaking activity and showing interest in the community affairs featured in the theoretical assumptions of both transformational leadership and participatory leadership model. Knowledge about the functioning of the public sector and involvement in public affairs are prerequisites for the implementation of participatory mechanisms (Irvin, Stansbury, 2004). The research carried out by the author shows that, according to the majority of the surveyed respondents, both the level of knowledge of municipality residents (Table 2), and the level of involvement in public affairs (Table 3) was rated as "average"6.

Table 2. What is the level of knowledge of the local community members about the functioning of the public sphere and the implementation of public tasks?

\begin{tabular}{|l|c|c|}
\hline \multicolumn{1}{|c|}{ The level of knowledge } & Number $(\mathbf{N = 5 2 2})$ & Perecentage (\%) \\
\hline Very low & 16 & 3,1 \\
\hline Low & 124 & 23,8 \\
\hline Medium & 320 & 61,2 \\
\hline High & 58 & 11,1 \\
\hline Very high & 4 & 0,8 \\
\hline Total & 522 & 100,0 \\
\hline
\end{tabular}

Source: author's own study.

\footnotetext{
5 The people involved, for example, in the implementation of the participatory (civic) budget as initiators of projects, participants of public consultations, participants of meetings organized by municipal authorities.

6 This rather "safe" answer to the questions may have stemmed from a lack of awareness on the part of the authorities about the level of residents' knowledge and could have been their subjective assessment. No research was conducted on this subject in any of the studied municipalities. The questions of this sort also pose the problem that, for the sake of political correctness, internal matters of the municipality are never spoken of negatively outside the municipality.
} 
Table 3. What is the level of involvement of local community members in the municipal matters?

\begin{tabular}{|l|c|c|}
\hline \multicolumn{1}{|c|}{ The level of involvement } & Number & Perecentage (\%) \\
\hline Very low & 10 & 1,9 \\
\hline Low & 90 & 17,1 \\
\hline Medium & 327 & 62,3 \\
\hline High & 94 & 17,9 \\
\hline Very high & 4 & 0,8 \\
\hline Total & 525 & 100,0 \\
\hline
\end{tabular}

Source: author's own study.

The results of other nationwide surveys also point to the low interest of citizens in public affairs and the scope for exerting influence on decisions taken. The interest in current politics is somewhat better. However, it is still only the reception of information, not active participation. In a survey conducted in 2011, half of the respondents admitted that the municipal matters were of little interest to them, while every third person indicated that they were interested in them moderately (cf. Celiński et.al, 2011; Starzyk-Durbacz, 2016; Łabędź, 2016).

At the same time, despite the poor interest of the residents in municipal matters, the authorities of only one in every fifth municipality undertook educational activities in the field of participation (Table 4). Considering the type of municipality, it should be pointed out that these were mainly urban and urban-rural municipalities (Table 5).

Table 4. Did the municipal authorities carry out educational projects for residents regarding participation and involvement in public affairs?

\begin{tabular}{|l|c|c|}
\hline & Number $(\mathbf{N}=\mathbf{5 2 5})$ & Perecentage $(\%)$ \\
\hline Yes & 115 & 21,9 \\
\hline No & 410 & 78,1 \\
\hline Total & 525 & 100,0 \\
\hline
\end{tabular}

Source: author's own study.

Table 5. Did the municipal authorities carry out educational projects for residents regarding participation and involvement in public affairs?

\begin{tabular}{|l|c|c|c|c|}
\hline \multirow{2}{*}{} & \multicolumn{3}{|c|}{ Type of municipality (data in \%) } & \multirow{2}{*}{ Total } \\
\cline { 2 - 4 } & urban* & urban-rural & rural & \\
\hline Yes & 42,2 & 31,3 & 16,6 & 21,9 \\
\hline No & 57,8 & 68,7 & 83,4 & 78,1 \\
\hline Total & 100,0 & 100,0 & 100,0 & 100,0 \\
\hline
\end{tabular}

* this category also includes municipalities with district rights

Source: author's own study. 
A vast majority of municipality representatives asked about the benefits of local community participation admitted that, in their opinion, it contributes to a better adaptation of the measures undertaken by the authorities to the needs and expectations of the residents (Table 6). It is difficult to unequivocally verify to what extent they actually see the benefits of participation. These indications are not fully confirmed in the interviews.

Table 6. Does participation of the local community in the planning and implementation of public policies contribute to a better adaptation of activities to the local needs?

\begin{tabular}{|l|c|c|}
\hline & Number $\mathbf{( N = 5 2 2 )}$ & Perecentage (\%) \\
\hline Definitely no & 1 & 0,2 \\
\hline Rather no & 9 & 1,7 \\
\hline Neither yes nor no & 32 & 6,1 \\
\hline Rather yes & 291 & 55,8 \\
\hline Definitely yes & 189 & 36,2 \\
\hline Total & 522 & 100,0 \\
\hline
\end{tabular}

Source: author's own study.

By contrast, the respondents asked about specific benefits that, in their opinion, result from the public involvement of the local community pointed to, inter alia, better identification of local needs $(67.6 \%)$, improvement of the communication process $(35 \%)$, raising residents' awareness about the functioning of local government (28.6\%), improving relations between the authorities and residents (27.2\%), and building a sense of community $(26.5 \%)$. Only $10 \%$ of the respondents indicated that the participation of residents in the municipal matters may give the community a sense of influence on making decisions and enable co-decision?

The awareness of the potential benefits of local communities' participation in the processes of local decision-making did not correspond with the answers to the question about the so-called participatory infrastructure, i.e. the available instruments of participation (including the use of optional solutions $)^{8}$ and preparation of the municipal office for the active participation of residents in the processes of deciding on local matters (Nabatchi, Leighninger, 2015). In less than half of the surveyed municipalities (42.9\%), a separate organizational unit was designated in the municipality office, or a person was delegated to deal with the issues of public participation and cooperation with municipality residents. In more than half of these municipalities, one person was involved in the issues of participation, yet in none of the researched municipalities it was the only job of a delegated person, but an additional duty (Table 7).

\footnotetext{
${ }^{7}$ In case of this question, it was possible to select more than one answer.

8 The survey included the question about implementing in the researched municipalities instruments of participation, such as social councils of various types, committees, consultative and advisory teams, forums of debate and dialogue, as well as the use of the so-called new forms of studying public opinion on a given topic, such as civic cafes, a civic walk, etc. The objective was to verify whether the municipalities implement other than typical participatory mechanisms such as social consultations and referenda (cf. Kalisiak-Mędelska, 2015).
} 
Table 7. Who is responsible for cooperation with social organizations and local community in the municipality office?

\begin{tabular}{|l|c|c|}
\hline \multicolumn{1}{|c|}{ The entity responsible for cooperation } & Number $(\mathbf{N = 2 2 5 )}$ & Perecentage (\%) \\
\hline A delegated person & 117 & 52,0 \\
\hline A team of employees & 43 & 19,1 \\
\hline $\begin{array}{l}\text { Separate department for cooperation with social } \\
\text { organizations }\end{array}$ & 36 & 16,0 \\
\hline $\begin{array}{l}\text { Tasks in this area are assigned to the promotion } \\
\text { department }\end{array}$ & 23 & 10,2 \\
\hline $\begin{array}{l}\text { An office for social participation functions in the } \\
\text { office structure }\end{array}$ & 2 & 0,9 \\
\hline $\begin{array}{l}\text { Participation matters are dealt with by a separate } \\
\text { organizational unit (outside the structure of the } \\
\text { municipal office) }\end{array}$ & 2 & 0,9 \\
\hline $\begin{array}{l}\text { Other person/unit } \\
\text { Total }\end{array}$ & 225 & 0,9 \\
\hline
\end{tabular}

Source: author's own study.

Table 8. Forms of sharing information about local matters

\begin{tabular}{|c|c|c|c|c|}
\hline \multirow{2}{*}{ Way of informing residents } & \multicolumn{3}{|c|}{$\begin{array}{c}\text { Type of leader (value of the social } \\
\text { support index - WPS)* }\end{array}$} & \multirow{2}{*}{$\begin{array}{c}\text { Municipalities } \\
\text { in total }\end{array}$} \\
\hline & $\begin{array}{l}\text { low } \\
(0-7)\end{array}$ & $\begin{array}{c}\text { medium } \\
(8-10)\end{array}$ & $\begin{array}{c}\text { high } \\
(11-14)\end{array}$ & \\
\hline $\begin{array}{l}\text { information on the website of the mu- } \\
\text { nicipality office }\end{array}$ & 2 & 5 & 3 & 10 \\
\hline $\begin{array}{l}\text { information on the board at the munici- } \\
\text { pality office }\end{array}$ & 2 & 5 & 3 & 10 \\
\hline information in local municipal press & 2 & 5 & 3 & 10 \\
\hline information in local media & 1 & 3 & 2 & 6 \\
\hline $\begin{array}{l}\text { meetings of the municipal authorities } \\
\text { with residents during which information } \\
\text { is provided }\end{array}$ & 1 & 3 & 1 & 5 \\
\hline social media & 0 & 0 & 1 & 1 \\
\hline $\begin{array}{l}\text { information passed on through village } \\
\text { heads, councilors, district housing } \\
\text { councilors }\end{array}$ & 0 & 1 & 1 & 2 \\
\hline Total & 2 & 5 & 3 & 10 \\
\hline
\end{tabular}

* the last row shows the total number of municipalities in particular intervals distinguished on the basis of the scale of social support for the executive body; the number of municipalities whose representatives provided a given answer in the survey is presented in individual cells.

Source: author's own study.

The above results of quantitative research show inconsistency in the approach to the issue of participation and the use of instruments of civic engagement in municipalities. Does the specificity of leadership thus determine the offer of tools for participation that the 
municipality residents can use? Considering the social support indicator for the municipality head described in the previous part of the article, it is difficult to conclude unequivocally that in the municipalities where the executive body is perceived as a social leader the level of participation (measured by the scale of participation instruments used) is higher. When comparing the values of the indicator with the responses regarding the methods used to inform residents about the municipality matters, there are no significant differences between the municipalities in which a formal leader exercises power, and those in which a formal leader also enjoys social support, and hence is a social leader as per the assumption adopted in this article (Table 8).

The above table shows that regardless of the specific character of a local leader, similar and quite typical ways of informing residents about the situation of an individual tend to be used in municipalities (Kalisiak-Mędelska, 2015). Information meetings are organized only sporadically. In the case of rural municipalities, the village heads are an important information channel (Matysiak, 2013; Ptak, 2016).

The differences can be noted, however, by juxtaposing the type of leader with the instruments of participation used. In the case of municipalities in which the executive body enjoyed social support (medium and high), and hence was a social leader, the mechanisms that go beyond obligatory solutions such as consultations of an annual cooperation program with organizations or consultations of revitalization programs were used more often (Table 9).

Table 9. The type of leader and the use of participation instruments in the researched municipalities

\begin{tabular}{|c|c|c|c|c|}
\hline \multirow{2}{*}{$\begin{array}{c}\text { Selected instruments of public } \\
\text { participation }\end{array}$} & \multicolumn{3}{|c|}{$\begin{array}{c}\text { Type of leader (value of the social support } \\
\text { index - WPS)* }\end{array}$} & \multirow{2}{*}{ Total } \\
\hline & $\begin{array}{l}\text { low } \\
(0-7)\end{array}$ & $\underset{(8-10)}{\operatorname{medium}}$ & $\begin{array}{c}\text { high } \\
(11-14)\end{array}$ & \\
\hline $\begin{array}{l}\text { functioning of permanent councils/ } \\
\text { teams/consultative and advisory } \\
\text { committees }\end{array}$ & 0 & 1 & 2 & 3 \\
\hline $\begin{array}{l}\text { council/panel for the participatory } \\
\text { (civic) budget }\end{array}$ & 0 & 2 & 3 & 5 \\
\hline municipal youth council & 0 & 2 & 2 & 4 \\
\hline senior council & 0 & 2 & 1 & 3 \\
\hline $\begin{array}{l}\text { task/problem councils appointed } \\
\text { when needed }\end{array}$ & 0 & 1 & 0 & 1 \\
\hline $\begin{array}{l}\text { functioning of the local council/ } \\
\text { social dialogue commission }\end{array}$ & 0 & 0 & 1 & 1 \\
\hline a public debate forum is organized & 0 & 0 & 1 & 1 \\
\hline $\begin{array}{l}\text { new participatory techniques (e.g. } \\
\text { open space, citizens' cafe, delibera- } \\
\text { tive survey, transect walk) }\end{array}$ & 0 & 1 & 1 & 2 \\
\hline $\begin{array}{l}\text { lack of other forms of citizen partici- } \\
\text { pation }\end{array}$ & 2 & 3 & 0 & 5 \\
\hline Total & 2 & 5 & 3 & 10 \\
\hline
\end{tabular}

Source: author's own study. 
The above table shows that facultative forms of participation are applied in the case of municipalities in which the authorities enjoyed high social support. These solutions were used more often in the case of urban and urban-rural municipalities, which results from the professionalization of these local governments, human resources capacity, professional qualifications of the staff, as well as knowledge and social involvement. In the case of small municipalities, some authorities - as verified during in-depth interviews - did not see any point in using formalized tools for participation in order to hear the opinions of residents, pointing to constant, direct contact with the local community. At the same time, meetings with residents were treated by the local authorities not only as an opportunity to provide information about the municipality and the wish to obtain feedback from the residents, but also to promote themselves. This is evidenced by the following opinion of a municipality head:

No, it's not that simple [using different tools of participation - A.K.] But ... so from this point of view, from the fact that I have to - well, I do not have to, I actually don't have to, but I go. All thirty-three village meetings, I will go everywhere these meetings are held, I will talk with these people. From this point of view, it is obviously, personally for me, I think a certain bonus. I mean, I do not know, of course, elections... [ M/I/W/GW-WPS ${ }^{9}$.

In the case of those in power for another term, the formalized tools of participation did not always prove effective. They were often perceived as an opportunity to promote a municipality. Some of the tools of participation were used because of "fads" and prevailing trends. Their application did not result from a real need, but necessity to follow other municipalities which implemented a given solution, e.g. a civic budget (interview: D/I/KWSP). Familiarity with local reality of a given municipality and its community meant that recognition of social needs was possible without adopting formalized solutions. A direct contact with residents proved to be much more effective and preferred by the authorities also in large cities. That was evidenced by the following opinion:

Because it is such a man. Since 2002 ... well. The president is really at every party. Literally every party. At this point, the president has no time in September and October, because there are so many events. He's constantly occupied. Signups for appointment with the President on Tuesday, that is, on this day, which I do not want to talk about, as we call it [open day for residents - A.K.] are.... I do not know, they are maybe in October? And the president goes everywhere. [D/I/U-WSP].

According to some of the researched municipal authorities, a low level of awareness and commitment to public affairs makes it pointless to implement some formal solutions. A fairly critical approach to individual tools of participation does not mean, however, that

\footnotetext{
${ }^{9}$ Coding of interviews - the rules: the first letter means the region (Polish: województwo), the Roman number - the municipality's number in a given region, the subsequent letter means the respondent's function: W -leader of rural municipality, B - mayor, P - president, and last part of the code describe a type of a municipality: GW - rural municipality, GMW - urban-rural municipality, GM - urban municipality (including municipalities with district rights, those which combine tasks of municipalities and districts), WPS-high social support, SPS - medium social support, NPS - low social support.
} 
the authorities see no need to activate the local community and boost its participation in the affairs of the municipality.

[...] people see this availability, that they can come (...), that we are not just clerks, we are just like partners for them, because we are out there for them and they know it. One will come, the second and tenth will come ...so, this cooperation is definitely "open". I say, we do not close the door and whenever there is an idea, we are happy. (...) You have to talk to the residents and that's all, because then we know their position, and if we only put up the "consultations" in the internet, it's ...: Municipality council is all about talking to people, because it's the basis, because as I say, I still hold on to it. On the higher level there are fewer opportunities, conversations, but here we should do it that way, we do it and think that everyone ... [P/I/W/GW-NPS].

In the course of the research, it was observed that social activity in the researched municipalities was identified with public participation. These are related categories, albeit not identical. Activity is a prerequisite for public participation (Kaźmierczak, 2011; Inlot-Brzęk, 2017). And it was commonly a starting point for municipality authorities (especially the social leaders) to launch the process of including communities in public affairs. In the majority of surveyed municipalities, the activity of the organizations and the emergence of new social entities were pointed out, which in the opinion of the respondents indicated the involvement of local communities in public affairs. Social leaders were usually those who played a key role in these activities. This is evidenced by the following statement of one of the councilors, who commented on the role of the mayor in the process of activating a local community:

The mayor has been holding his office for a few terms now, and I think that this development of associations, generally needs to be attributed to him, his activity, he is very much focusing on it, and that's why in our municipality it just looks very thriving, so I would say. But this is the role of the mayor. It is him, however, who cares about this association, that these facilities are renovated, that these depots are refurbished and these active women are mobilized [informal women's organizations and rural women associations - A.K.], it must be said that it is his merit. Here, the mayor, who put his services [employees of the office - A.K.] on the highest level so that they simply support it completely. [L///RP/GMW-WPS].

\section{CONCLUSIONS}

Analyzing the way of exercising leadership in the researched municipalities, one can notice the elements typical for both the transformational and participative leadership model. Considering the results of quantitative research, no clear differences between the scope of applied instruments of participation and the type of leadership in the researched municipalities can be observed. The conducted interviews enabled to verify the authorities' approach to participation and the instruments used. They show that municipal authorities are aware of the mechanisms of participation, but generally perceive them as unnecessary and difficult to implement. It is notable that the municipalities in which the executive body enjoyed social support have developed their own, local ways of contacting residents, seeking their opinions and articulating needs, which in most instances are based on direct contact. In the case of small units, the possibility of permanent direct contact with the municipality authorities practically replaces the instruments of participation. The research did not identify 
a single example of municipality in which a limited scope of instruments of participation (i.e. going beyond the mandatory solutions) stemmed from the authorities' fear of losing power.

An indifferent or negative attitude to participative solutions resulted primarily from a low - according to the respondents - involvement of residents, their low interest in the affairs of the municipality and a lack of knowledge about the functioning of the local government, as well as the use of mechanisms of participation. In summary, it can be concluded that in the case of the researched municipalities, the scale of social support has little impact on the scope of applied tools of participation. What is noticeable, however, is the relationship between the size of a municipality and a range of available mechanisms of public participation. Using other than obligatory tools of public participation in urban municipalities stems from their human resources capacity, knowledge about participation processes, financial capacity and slightly greater awareness of a local community. Nevertheless, it should be remembered that this does not always translate into greater involvement of a local community (using available instruments). In turn, a low interest in the mechanisms of participation in small municipalities does not fully testify to the lack of interest of the inhabitants of these units in public affairs. In these municipalities, traditional ways of informing residents about the planned activities ${ }^{10}$ and contacting the authorities (mainly in a direct form) still prevail.

\section{REFERENCES}

Arnstein, R.S. (1969). A Ladder of Citizen Participation. "Journal of the American Planning Association" Vol. 35, No. 4.

Avolio, B.J., Walumbwa, F.O., Weber, T.J. (2009). Leadership: Current Theories, Research, and Future Directions. “Annual Review of Psychology” No. 60.

Barbuto, J.E., Fritz, S.M., Matkin, G.S. (2001). Leaders' bases of social power and anticipation of targets' resistance as predictors of transactional and transformational leadership. "Psychological Reports" Vol. 89, No. 3.

Bass, B.M., Wildman, D.A., Avolio, B.J. (1987). Transformational Leadership and the Falling Dominoes Effect. “Group \& Organization Studies" Vol. 12, No. 1.

Bass, B.M. (198). Leadership and Performance. New York: Free Press.

Bass, B.M., Avolio, B.J. (1994). Improving Organizational Effectiveness Through Transformational Leadership. Thousand Oaks, London, New Dehli: Sage Publications.

Bass, B.M., Bass, R. (2008). The Bass Handbook of Leadership: Theory, Research, and Managerial Applications 4th Edition, New York: Simon\&Schuster.

Bass, B.M., Riggio, R.E. (2006). Transformational Leadership, $2^{\text {nd }}$ Edition. Mahwah: Lawrence Erlbaum Associates.

Béné, C., Neiland, A.E. (2006). From Participation to Governance. A Critical Review of the Concepts of Governance, Co-management and Participation, and Their Implementation in Small-Scale Inland Fisheries in Developing Countries. Penang: World Fish Center.

Bennis, W., Nanus, B. (1985). Leaders: Strategies for taking charge. New York: Harper\&Row. Bovaird, T. (2005). Public governance: Balancing stakeholder power in a network society. "International Review of Administrative Sciences" Vol. 71, No. 2.

${ }^{10}$ In some of the researched rural and urban-rural municipalities, the most effective form of transmitting important information was a circular, i.e. an information letter passed from home to home. 
Bryson, J.M., Quick, K.S., Slotterback, C.S., Crosby, B.C. (2012). Designing Public Participation Processes. "Public Administration Review" Vol. 73, No. 1.

Burns, J.M. (1978). Leadership, New York: Harper\&Row.

Celiński, A. et al. (2011). Raport końcowy z badania efektywności mechanizmów konsultacji spotecznych (znak sprawy: 43/DPP/PN/2009). Warszawa.

Chaleff, I. (1995). The Courageous followers: Standing up to and for our leaders. San Francisco. Crosby, B.C., Bryson, J.M., Middleton Stone, M. (2015). Designing and Implementing CrossSector Collaborations: Needed and Challenging. "Public Administration Review" Vol. 75, No. 5.

Currie, G., Lockett, A. (2007). A critique of transformational leadership: Moral, professional and contingent dimensions of leadership within public services organizations. "Human Relations" Vol. 60, No. 2.

Dawkins, H.A. (2011). Transformational Leadership: A Contribution to the Effectiveness of Congregationally Formed Faith-Based Community Development Corporations, St. John Fisher College Fisher Digital Publications [Access: 2018.08.28]. Downloaded from: https://fisherpub.sjfc.edu/cgi/viewcontent.cgi?article $=1064 \&$ context=education_etd

Dumdum, U.R., Lowe, K.B., Avolio, B.J. (2002). Meta-Analysis of Transformational and Transactional Leadership Correlates of Effectiveness and Satisfaction: An Update and Extension [in:] Avolio, B.J., Yammarino, F.J., eds., Transformational and Charismatic Leadership. The Road Ahead. Bingley: Emerald Group Publishing Limited.

Enserink, B., Monnikhof, R.A.H. (2003). Information Management for Public Participation in Co-Design Processes: Evaluation of a Dutch Example. "Journal of Environmental Planning and Management" Vol. 46, No. 3.

Friend, J.K., Hickling, A. (2003). Planning under Pressure: The Strategic Choice Approach, Third Edition. Oxford: Heinemann.

Gawlik, P. (2017). Plan PiS: likwidacja II tury w wyborach samorzadowych. Kto na tym zyska, kto straci? [ANALIZA], „Gazeta Wyborcza” z 7.03.2017 r. [Access: 2018.08.31]. Downloaded from: http://wyborcza.pl/7,75398,21463244,plan-pis-likwidacja-ii-tury-w-wyborach-samorzadowych-kto-na.html.

Gendzwiłł, A., Swianiewicz, P. (2017). Czy potrzebujemy limitu kadencji w samorzadzie? Warszawa: Fundacja im. S. Batorego.

Gill, R. (2011). Theory and Practice of Leadership, SAGE. London 2011.

Goleman, D. (2000). Leadership That Gets Results. "Harvard Business Review” March-April 2000, No. 4487.

Gress, D.H. (1974). Participatory leadership: leadership characteristics of secondary school principals and their relationship to perceived subordinate participation in the decision-making process, Iowa State Repository [Access: 2018.08.28]. Downloaded from: https://lib.dr. iastate.edu/cgi/viewcontent.cgi?referer=https://www.google.com/\&httpsredir=1\&article= $6144 \&$ context $=$ rtd.

Habuda, L. (2007). Wójt (burmistrz, prezydent) gminy. Menedżer i polityczny lider. „Wroctawskie Studia Politologiczne” No. 8.

Heifetz, R.A., Sinder, R.M. (1988). Political Leadership: Managing the Public's Problem Solving [in:] Reich, R.B., ed., The Power of Public Ideas. London, Cambridge: Harvard University Press.

House, R.J., Dorfman, P.W., Javidan, M., Hanges, P.J., de Luque, M.F.S. (2014). Strategic Leadership Across Cultures: GLOBE Study of CEO Leadership Behavior and Effectiveness in 24 Countries. Thousand Oaks: SAGE. 
$\mathrm{Hu}$, J. (2017). Leadership theory in clinical practice. "Chinese Nursing Research" Vol. 4, No. 4.

Indulski, G. (2001). Jeśli nie przywódca, to kto? [w:] Bodio, T., red. Przywództwo polityczne. Warszawa: Elipsa.

Inglot-Brzęk, E. (2017). Znaczenie roli władz samorzadowych w kształtowaniu partycypacji obywatelskiej. „Nierówności Społeczne a Wrrost Gospodarczy” No. 50.

Irvin, R., Stansbury, J. (2004). Citizen Participation in Decision Making: Is It Worth the Effort? "Public Administration Review" no. 64/1, pp. 55-65.

Jakson, W. (2012). Absolutorium w jednostkach samorzadu terytorialnego - postulaty de lege ferenda, „Zeszyty Naukowe WSEI seria: ADMINISTRACJA” No. 2/1.

Kalisiak-Mędelska, M. (2015). Partycypacja społeczna na poziomie lokalnym jako wymiar decentralizacji administracji publicznej w Polsce. Łódź: Wydawnictwo Uniwersytetu Łódzkiego. Kaźmierczak, T. (2011). Partycypacja publiczna: pojęcie, ramy teoretyczne [w:] Olech, A., red., Partycypacja publiczna. O uczestnictwie obywateli w życiu wspólnoty lokalnej. Warszawa: ISP. Kellerman, B. (1988). Followership: How followers are creating change and changing leaders. Boston: Harvard Business Press.

Kołomycew, A. Kotarba, B. (2018a), Interes polityczny w realizacji polityki oświatowej. Warszawa: Scholar.

Kołomycew, A., Kotarba, B. (2018b). Styl przywództwa a interes polityczny i racjonalność organu wykonawczego gminy $w$ realizacji polityki oświatowej. „Samorząd Terytorialny” No. 7-8.

Król, M. (2014). Frekwencja w wyborach samorzadowych, ResPublica z 30.10.2014 r. [Access: 2018.08.28]. Downloaded from: http://publica.pl/teksty/48077-48077.html.

Krukowska, J. (2018). Staż burmistrza na stanowisku a jego poglady na zarzadzanie gmina. „Samorząd Terytorialny” No. 7-8.

Kuć-Czajkowska, K., Sidor, M., Wasil, J. (2017). Konsekwencje systemu wyborczego do miejskich samorzadów w Polsce - wybrane problemy. „Acta Politica Polonica” No. 3 (41).

Łabędź, K. (2016). Aktywność obywatelska na poziomie lokalnym i jej determinanty: na przykładzie Krakowa. „Polityka i Społeczeństwo” No. 4 (14).

Lang, R. (2014). Participative leadership in cross-cultural leadership research: A misconception? [in:] Kranz, O., Steger, T.O., eds., Zwischen Instrumentalisierung und Bedeutungslosigkeit Mitarbeiter-Partizipation im organisationalen Kontext in Mittel- und Osteuropa. Publisher: Hampp Verlag.

Martin, B., Cashel, Ch., Wagstaff, M., Breunig, M. (2006). Outdoor Leadership: Theory and Practice. Champaign: Human Kinetics.

Matysiak, I. (2013). Sottysi i sołtyski o petnionych rolach i motywacjach sprawowania funkcji w wybranych środowiskach wiejskich. „,Wieś i Rolnictwo” No. 3 (160).

Mikołajczyk, J. (2011). Teoretyczne aspekty przywództwa w samorządzie gminnym i problemy jego realizacji na tle nowych koncepcji uprawniania polityki lokalnej, [in:] Kasińska-Metryka, A. ed., Studia nad przywództwem politycznym. Ustalenia metodologiczne i praktyka. Toruń: Wydawnictwo Adam Marszałek.

Moynihan, D.P., Pandey, S.K., Wright, B.E. (2014). Transformational Leadership in the Public Sector: Empirical Evidence of its Effects [in:] Dwivedi, Y. K., Shareef, M.A., Pandey, S.K., Kumar, V., eds., Public Administration Reformation: Market Demand from Public Organizations. New York, London: Routledge/Taylor and Francis. 
Nabatchi, T., Leighninger, M. (2015). Public Participation for 21st Century, New Jersey: Jossey-Bass A Wiley Brand, John Wiley \& Sons.

Nocoń, J. (2008). Kryteria wytaniania lokalnych liderów politycznych [w:] Michałowski, S., Kuć-Czajkowska, K., red., Przywództwo lokalne a ksztattowanie demokracji partycypacyjnej. Lublin: Wydawnictwo UMCS.

Panicz, U. (2013). Frekwencja wyborcza a stan polskiej demokracji. „,Refleksje” No. 4.

Parvin, P. (2018). Democracy Without Participation: A New Politics for a Disengaged Era. "Res Publica” Vol. 24, No. 1.

PKW. (2014). Wybory i referenda [Access: 2018.08.28]. Downloaded from: http://pkw. gov.p1/352_Wybory_i_referenda.

Ptak, A. (2016). Sotectwa w lokalnym systemie wtadzy. Warszawa: Wydawnictwo Naukowe Scholar.

Quick, K.S., Bryson, J. (2016). Theories of public participation in governance. Chapter 12 [in:] An, sell, Ch., Torfing, J. eds., Handbook of Theories of Governance, Publisher: Edward Elgar [2018.08.28]. Downloaded from: https://www.researchgate.net/publication/282733927_ Theories_of_public_participation_in_governance.

Rabie, R. (2013). Structure or Process? Facilitative Leadership in the context of Knowledge Work - A Practitioners Perspective. Stellenbosch.

Raczkowski, K. (2015). Zarzadzanie publiczne. Teoria i praktyka. Warszawa: Wydawnictwo Naukowe PWN.

Saucier Lundy, K., Janes, S. (2009). Community Health Nursing: Caring for the Public's Health. Sudbury: Jones and Bartlett Publishers.

Schwarz, R. (2005). Using facilitative skills in different roles [in:] Schwarz, R., Davidson, A., Carlson, McKinney, S., The Skilled Facilitator Fieldbook. Tips, Tool, and Tested Methods for Consultants, Facilitators, Managers, Trainers, and Choaches. San Francisco: Jossey-Bass.

Sielski, J. (2012). Przywódcy i liderzy samorzadowi (lokalni), „Prace Naukowe Akademii im. Jana Długosza w Częstochowie, Seria Res Politicae”, Vol. 4, Special edition.

Starzyk-Durbacz, K. (2016). O partycypacji. Podsumowanie badań i analiz dotyczacych partycypacji obywatelskiej w Polsce. Warszawa: Pracownia Badań i Innowacji Społecznych „Stocznia".

Stoker, G. (2006). Why Politics Matters: Making Democracy Work. Basingstoke: Palgrave Macmillan.

Szacki, W. (2011). Mniejszość da władze (24 września 2011), „Gazeta Wyborcza”, [Access: 2018.09.01]. Downloaded from: http://wyborcza.pl/1,76842,10346490,Mniejszosc_da_wladze.html.

Weber, M. (2009). The Theory of Social and Economic Organization (translated by A.M. Henderson, T. Parsons). New York: The Free Press.

WHO. (2016). Open mindsets. Participatory Leadership for Health, Flagship Report 2016. Geneva: World Health Organization.

Winkler, I. (2010). Contemporary Leadership Theories. Enhancing the Understanding of the Complexity, Subjectivity and Dynamic of Leadership. Dordrecht, London, New York: Phisica-Verlag, Springer Heidelberg.

Yang, K., Pandey, S.K. (2011). Further Dissecting the Black Box of Citizen Participation: When Does Citizen Involvement Lead to Good Outcomes? "Public Administration Review" Vol. 71, No. 6. 
Żerkowska-Balas, M., Kozaczuk, A. (2013). Obywatele i wybory, Raport Fundacji Batorego. Warszawa: Fundacja im. Stefana Batorego.

Żukiewicz, P. (2011). Przywództwo polityczne. Teoria i praktyka. Warszawa: Difin.

DOI: 10.7862/rz.2019.hss.15

The text was submitted to the editorial office: September 2018.

The text was accepted for publication: June 2019. 